\title{
Community Participation on Water Resources Management in the Drought Prone Area (A Case Study from Wonogiri Village, Central Java, Indonesia)
}

\author{
Elok Surya Pratiwi ${ }^{1 *}$, Juhadi $^{1}$, Edy Trihatmoko ${ }^{1}$, Junun Sartohadi $^{2}$, Raulendhi Fauzanna ${ }^{1}$, Arif \\ Khoir Mahmud ${ }^{1}$. \\ \{eloksurya@mail.unnes.ac.id $\left.{ }^{1 *}\right\}$ \\ ${ }^{1}$ Universitas Negeri Semarang, Indonesia \\ ${ }^{2}$ Soil Science Department, Agriculture Faculty, Universitas Gadjah Mada, Indonesia
}

\begin{abstract}
Because geomorphological condition does not support the formation of good aquifer, the present of spring is becoming invaluable water resources for Wonogiri villagers to fulfill their domestics needs. The aim of this research is to investigate the community participation on spring management at the environment threatened by drought every year in Central Java, Indonesia. A field survey was conducted to interview some key informants related to management pattern applied in the village. We also observed directly the springs condition and land utilization surrounding the catchments area. A community organization which is responsible to protect the water quantity and quality was established to manage Ngureng spring as the main domestic water resources in study area. They manage the rate as well as the time of water usage. Both structural and non-structural protection activities were enforced to keep the water clean. Eventually, a lot of efforts have been shown by the community to minimize water scarcity when the dry season comes, but unfortunately it is only limited to the spring area and there is no land utilization management action yet in whole catchment that could give significant influence to the sustainability of the springs. This result could become a lesson learned related to community protection activities in rural area and hopefully, some improvement step could be taken to reduce the disaster risk in the future.
\end{abstract}

Keywords: Community Participation, Drought, Management, Spring, Water.

\section{Introduction}

Water is an essential resource for human life. It is used for both primary and secondary needs such as dinking, cooking, washing, sanitary, watering plans and industry. Besides acting as a user, human also have capability to manage water resource, so that their quantity and quality can be maintained [1]. However, each individual or community has different level and form in managing its resources, it depends on various things such as their financial condition, education level, social and physical environment [2]. 


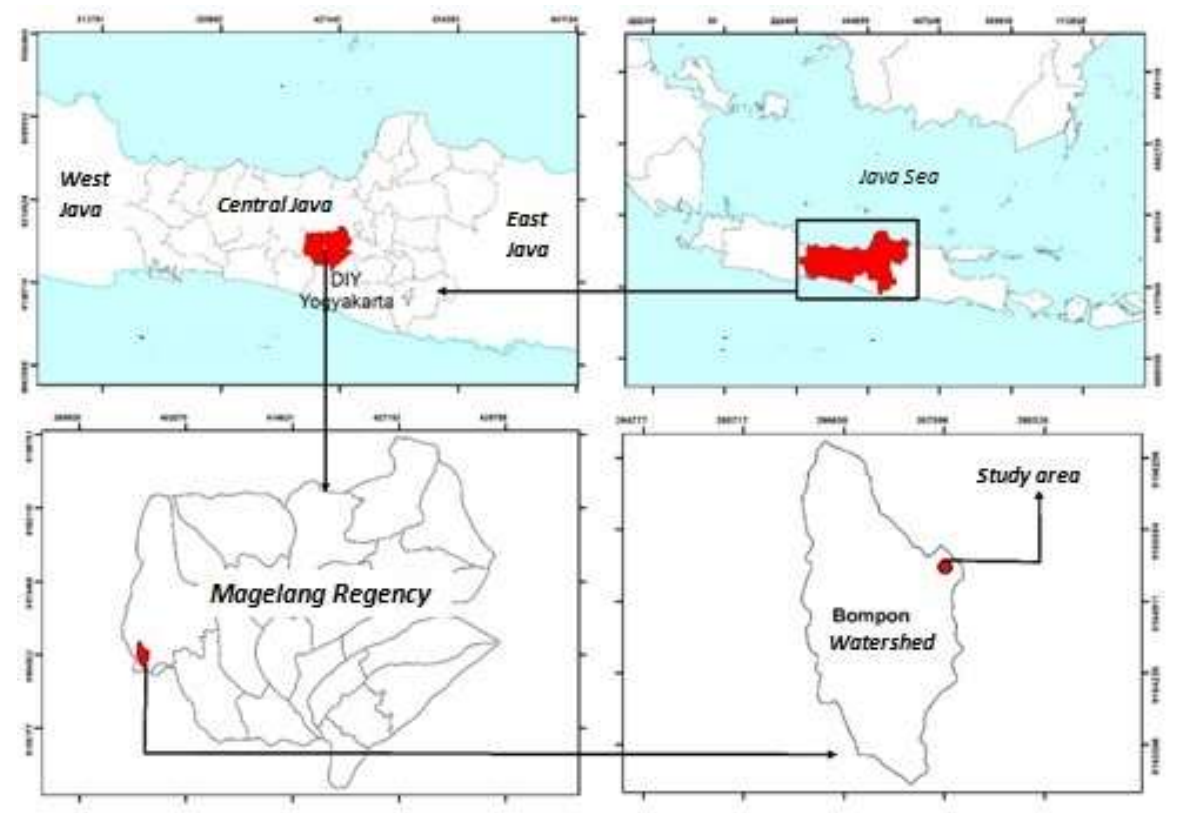

Fig. 1. Study area is located in Wonogiri village and it is part of Bompon watershed categorized as drought prone area in Magelang Regency.

Wonogiri village located on Magelang Regency is included into drought-prone area in Central Java Province. Because it is located in a hilly area covered by very deep clay, this region cannot form a good aquifer even though it has very large annual rainfall $(>3000 \mathrm{~mm})$. As a result, many people do not have wells due to the location of groundwater level is very deep and often dry during the dry season. This condition has urged villagers to find another water resources such as spring or seepage to fulfill their daily needs. From geographic site, this area is laid within a small catchment called Bompon watershed which has an area of $9 \mathrm{~km}^{2}$ approximately (Figure 1). There are 19 springs scattered on it and one of them is called Ngureng spring. The flow discharge of this spring comes up to $192 \mathrm{ml} / \mathrm{s}$ and becoming the main water resources of 90 households in that area.

Due to their historical experience on drought in the past, the villagers start to realize about the importance of giving participation on water management in their area. community participation could be in the form of energy, idea or willing to pay. Many studies related to community participation have been conducted in some area of Indonesia before [3][4], but research carried out in rural communities who lived in the drought-prone areas has never been studied before. This focused study is to investigate the kinds of participation on water resources management by the rural community who live in the drought prone area. Community participation in a certain area is really important to be learned in order to gain a better quality of life on the environment [5]. 


\section{Methods}

Collection of data concerning the participation of water management by local people are conducted through interviews with several key informants, which consists of the head of water source management, the village headman, and 2 consumers from local people. Direct observation also held in order to identify any forms of water source protection, from people both structural and non-structural. The observation taken place at the central point of the water source and at the entire water catchment area. Land's usage and conservation availability is the main focus relating to the observation in the water catchment area.

\section{Result}

\subsection{Community Organization}

An informal organization has been formed by the local people of Ngemplak neighborhood which is part of Wonogiri village, in order to manage the water resources systems of Ngureng spring. It was originally initiated in 2015 and was built using hamlet fund without any support from government. Due to that reason, that organization is completely running by local community in Ngemplak neighborhood without any interference from government officer. The organization's structure consists of the Headman, Vice headman, secretary, treasury and finance, and technician. Head of the organization appointed through internal group discussions. This organization is built genuinely by the people for the people, not just a mere money-oriented purpose or to gain individual profit.
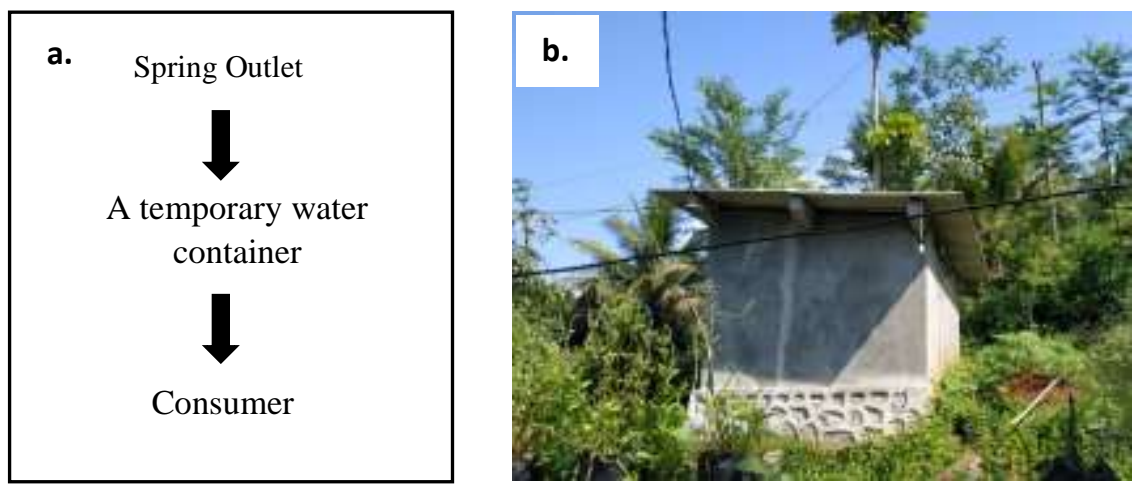

Fig. 2. a) water distribution steps organized by community in Wonogiri Village. b) the appearance of temporary water container to keep water before it is distributed to the villagers.

An organized and structured system has been built in order to support water distribution and ensure water movement on an equitable basis for domestic use. In terms of distributing the water, streaming water from the water source has to be allocated with a water pump beforehand for it will 
be forwarded directly into temporary distribution reservoirs (Figure 2a), which provided permanently and has volume for an approximately $16 \mathrm{~m}^{3}$ (Figure $2 \mathrm{~b}$ ). The water distribution reservoirs designed as a fully enclosed water storage system to protect stored water from external contamination, prevent water from fallen leaves, or can be function as a site where the deposition of sediment suspension occurred. Water is delivered afterwards from the water reservoir to the local's houses individually with linked pipes system that has been built by the locals.

The water system regulation differs the amount of distributed water seasonally as an anticipation of water scarcity issues in dry season (Table 1). On rainy days, water is delivered from 6 a.m to 10 p.m which equals 16 hours streaming without stopping. Water is delivered partly in two sessions on dry season, the first session will have water delivered began in the morning at 6 a.m for the next 6 hours while the night session began at 5 p.m for the next 5 hours. This may be likely to change due to conditional reasons such as water source discharge, whereas the distribution session will be cut in shorter period in order to maintain adequate water supply.

The organization run by local people also has a role in deciding the water usage tariffs, which determined under the group discussions. Water distribution depends on 3 different pipes, where each pipe has a different base tariffs (Table 2). The pipes used in that area is type number 2 which caused local citizen to pay monthly fees as much as Rp. 20.000/month. Raised funds will be addressed into several payments, such as treatment costs, maintenance costs, and to charge the caretaker of water source organization. Additional cost including the cost of leasing the land, as for the sites used for water systems typically owned by locals. This additional payment required as much as Rp. 300.000 to be paid once every 3 months. The remaining funds will be allocated to the villagers' savings.

Table 1. water distribution schedule created by community to maintain the quantity of annual water.

\begin{tabular}{ccc}
\hline Season & \multicolumn{2}{c}{ Operational Time } \\
\hline Rainy & \multicolumn{2}{c}{$6 \mathrm{am}-10 \mathrm{pm}$} \\
\cline { 2 - 3 } Dry & Session 1 & $6 \mathrm{am}-12 \mathrm{am}$ \\
& Session 2 & $5 \mathrm{pm}-22 \mathrm{pm}$ \\
\hline
\end{tabular}

Table 2. Type of water rate use installed in Ngureng Spring

\begin{tabular}{ccc}
\hline Category & Rate use of water $\left(\mathbf{m}^{3}\right)$ & Rate \\
\hline 1. & $0-10$ & $\mathrm{Rp} 1.500 / \mathrm{m}$ \\
2. & $11-20$ & $\mathrm{Rp} 2.000 / \mathrm{m}$ \\
3. & $21-30$ & $\mathrm{Rp} 3.000 / \mathrm{m}$ \\
\hline
\end{tabular}

\subsection{Protection Action}

The form of structural protection conducted by local people to maintain the water source, for instance is to build an artificial reservoir tank, typically as a pond or impoundment created from hard materials such as concrete (Figure 3). This artificial reservoir function is to store clean water and keep both its quality and quantity at the optimum level. It will also facilitate people in their activity of planning, developing and managing the optimum use of water resource. Another attempts as a participation act from local people to water management systems includes of providing nets to cover the water storage tanks for the control of water quality from external 
contamination such as falling leaves, which will be likely to settle and pollute the water. Unfortunately, the nets are no longer used for the current or even future due to inefficiency issue. Falling leaves, dust and other debris continue being a major threat to the water feature. When these wastes get into the water, they will start decaying, releasing harmful products which damage the water's quality and reducing the quantity.
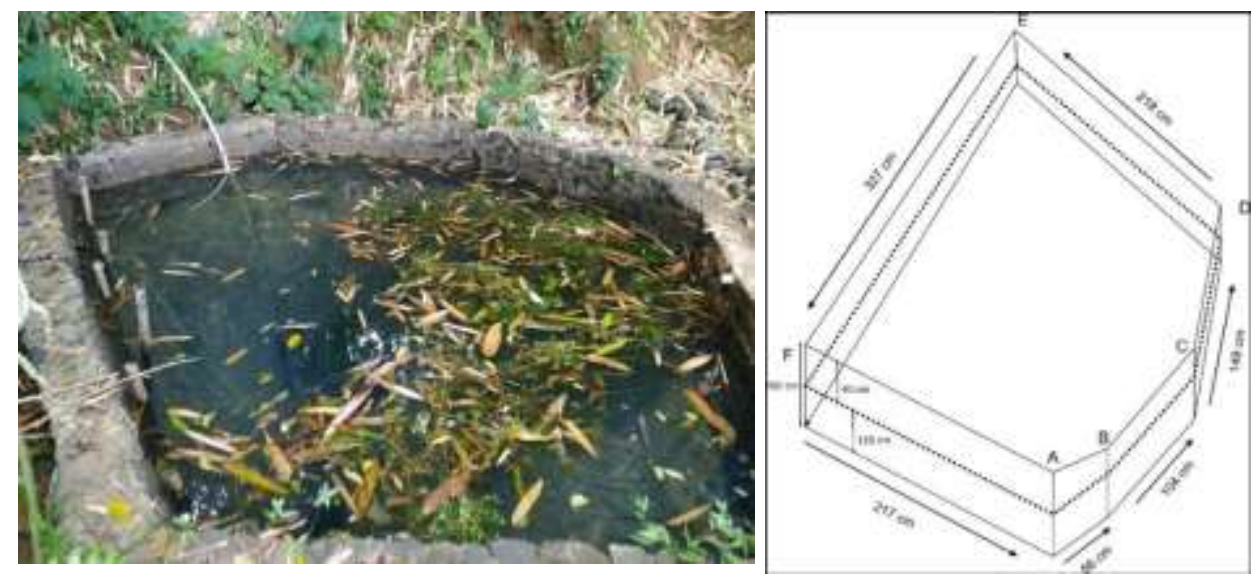

Fig. 3. the structural protection shape bordering the Ngureng spring outlet

Besides the structural protection attempts, local people also attempting in non-structural protection. The formed a daily schedule for cleaning chores of the water storage and held at least monthly socialization relating to the importance of keeping water resources clean. Generally, they will continue to clear up the water source area from wild plants. Keeping the water source free from any falling leaves and other debris regularly is also an essential thing to maintain a clean and healthy water source.

\section{Discussion}

Water source management activity conducted by local people from Wonogiri village is a form of a meaningful participation that will brings a positive development to water source sustainability. The raise of awareness concerning the importance of taking an actual participation to support water management is basically based on shrinking water supply issues on dry season that occurred annually. Previously the absence of protection effort regarding the water source has resulted the sites to be vulnerable to external pollutants and contaminations such as falling leaves, dust and other debris. With those kind of situation, has been causing local people to refuse using water source to satisfy their daily needs and demands. At first, people are preferably to seek water from PAMSIMAS (drinking water industry managed by society), which obtained their water from outside the watershed. However, there are many problems going on every now and then. While using water from PAMSIMAS, the most common problem is disconnected water supply and low 
water discharge at a drastic level despite on rainy season. This water scarcity continues to cause an armed conflict over water, leading to further social conflict and tensions. Dispute over water later on pushes an incentive to manage their own local water source.

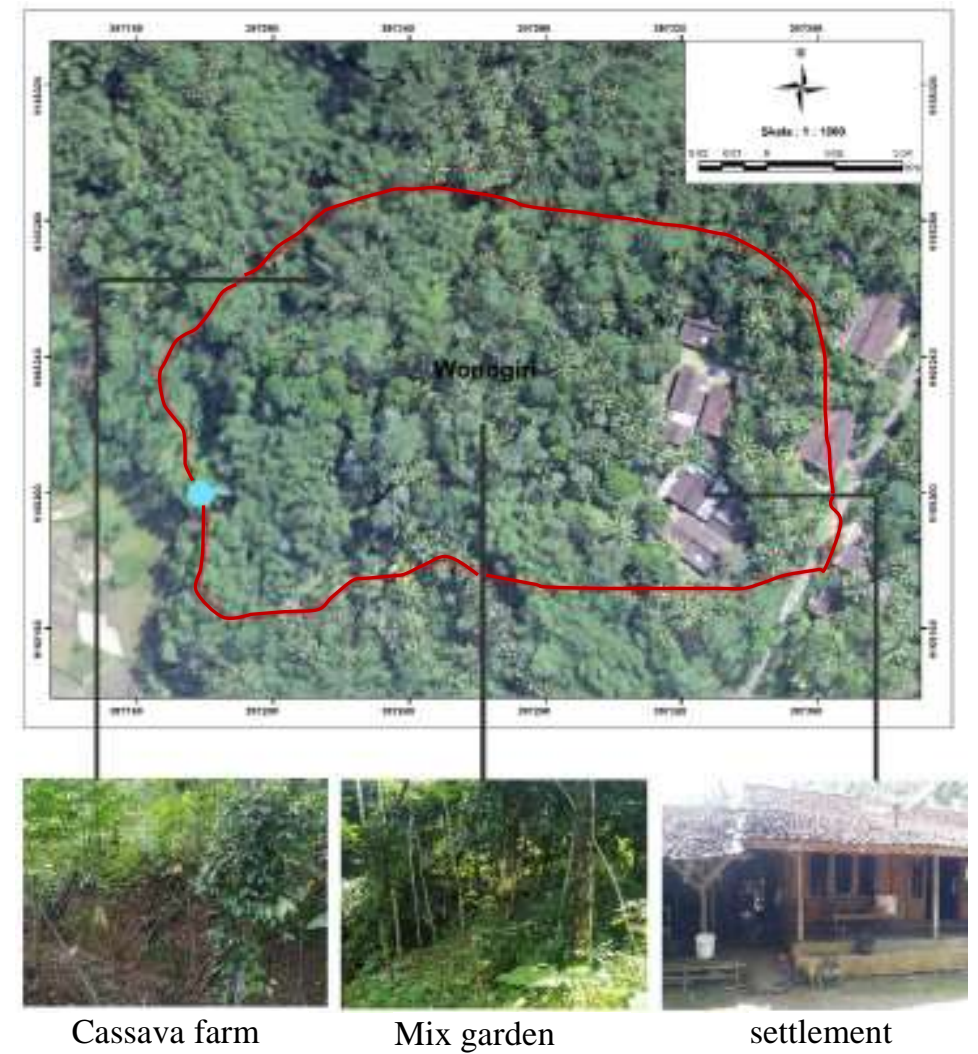

Fig. 4. Location of Ngureng spring outlet (blue dot), catchment border (red line) and its land utilities condition.

In spite of well-participated people in water source management, unfortunately the water catchment area has not been managed properly. The lack of activities and protection effort is due to uninformed people concerning the water catchment area management. As the conditions surrounding the water catchment area have an ultimate impact to the sustainability of a water source [6][7]. Land management planning in water catchment area is a major concern as it will decide how much water absorbed to the soil and becomes the source of a water supply.

The water catchment area is commonly used by local people as a mixed garden combined various types of plants and trees, such as Albizia chinensis, Tectona grandis, Lansium domesticum and Arenga pinnata. Vegetation roots have made the soils to loosen up which results water to be absorbed quickly and fills the water supplies. Nevertheless, the upstream area is at an alarming 
rate situation. Half of the area has been used in favor of settlement. Such buildings will increase run-off amount and reduce absorbed water to the soil, causing low input to the water supplies. Functional shift of the land from the primarily mixed gardens to a dry field is also a major threat to sustainability of water source. The usage of a fertilizer for seasonal plants have the potential to damage the quality of the coming water.

\section{Conclusion}

The local community from Wonogiri village have shown a real participation concerning the water source system management around their surroundings through forming an informal nonprofitable organization which role the development and sustainability of water sources. The organization has fully involving locals to directly participate, which impacting a raise of awareness towards environment and the land they lived on. Regardless of any available drawbacks, such attempts and efforts with kinship principles conducted altogether by the locals has decreased the water shortage issues in Wonogiri village without any social tension and conflict.

\section{References}

[1] Buwono, N. R. Muda, G. O. and Arsad, S.: Pengelolaan Mata Air Sumberawan Berbasis Masyarakat di Desa Toyomarto Kecamatan Singosari Kabupaten Malang. Jurnal Ilmiah Perikanan dan Kelautan (2017).

[2] Sudarmadji. Suprayogi, S. Widyastuti, M. and Harini, R.: Konservasi Mataair Berbasis Masyarakat di Unit Fisiografi Pegunungan Baturagung, Ledok Wonosari dan Perbukitan Karst Gunung Sewu, Kabupaten Gunung Kidul. Jurnal Teknosains Vol 1, No 1 (2011).

[3] Rahardjanto, A. K.: Studi Pendahuluan Model Pengelolaan Sumberdaya Air Partisipatif Akomodatif Guna Antisipasi Konflik Pembagian Air (Kasus Sumberawan Kecamatan Singosari Malang). Jurnal Studi Masyarakat Islam Volume 13 No 2 (2010).

[4] Sudarmadji, Darmanto, D, Widyastuti, M. and Lestari, S.: Springs Management for Sustainability Domestic Water Supply in the South West of Merapi Volcano Slope. J. Manusia dan Lingkungan, Vol. 23, No.1, pp: 102-110 (2016).

[5] Cadena-Inostroza C., Morales-Fajardo M.E.: Community Water Management and Quality of Life: The Independent Water Governance Committees in Toluca, Mexico. Quality of Life in Communities of Latin Countries pp 117-134 (2017)

[6] Tjakrawarsa, G. and Handoko, C. Study of Technique Protection of springs at Lombok Island Case study at The Rarung Research Forest. Indonesian Forest Rehabilitation Journal Vol. 1 No. 1, (2013).

[7] Setiawan, O. Sartohadi, J. Hadi, P. and Mardiatno, D.: Delineating Spring Recharge Areas Inferred From Morphological, Lithological, and Hydrological Datasets On Quaternary Volcanic Landscapes at the Southern Flank of Rinjani Volcano, Lombok Island, Indonesia. Acta Geophysica (2019). 